\title{
LOTTERY GAMBLING TRADITION IN AMERICA AS PORTRAYED IN SHIRLEY JACKSON'S THE LOTTERY AND ITS IMPACTS ON THE LOTTERY DEVELOPMENT IN INDONESIA
}

\author{
Nestiani Hutami \\ Alumni of American Studies Graduate Program
}

\begin{abstract}
Discussing about gambling practiced in western culture has always been a controversial phenomenon for there are abundant of both positive and negative effects. This phenomenon is portrayed in one of Shirley Jackson's works which is interesting to notice that she who is known for her mysticism in most of her works put lottery gambling tradition into her iconic short story entitled "The Lottery". However, although Jackson's idea about performing lottery is quite different from American society in general, she tries to depict the value of lottery itself as one of the preserved traditions in the United States. The great development of lottery gambling in America assuredly contributes to the growth of this gambling around the world. It does not only give impacts on the life of American people, but also on the life of people of other countries, especially Indonesia.
\end{abstract}

Keywords: lottery, tradition, controversy, value, development, impact.

\section{INTRODUCTION}

Discussing about gambling practiced in western culture has always been a controversial phenomenon. Many countries ceaselessly debate about the legality of this event, and even not least of them prohibit its existence. There is also no guarantee that gambling has more benefit or gives little loss to either individual or society. The existence of gambling has been known even before Christ, however in various forms, rules and packages. People from the past played gambling by holding animal races, such as dog race or horse race. Even in 1174 Henry II of
England established weekly horse races at country fairgrounds.

Gambling began to grow in America in 1620 where twenty mares were shipped from England to Virginia Colony, and horse racing with private wagering became a regular activity for the settlers (Thompson, 2001, p.ix). McDowell states that "many social scientists accept both past and present and the others are moving in the same direction" (McDowell, 1948, p.7). It is a common thought that now America has become the leading country for gambling tradition. This idea is based on one of the cities in United States that holds this event massively. People 
around the world will go to Las Vegas to play casino, poker, or other gambling games. The games held in this city are quite different from the games people played in the past times.

Although the basic rules are mostly the same, the technologies used are very much different. Nowadays, people tend to create modern and sophisticated devices of gambling games to get more benefit from it. The tradition of playing gamble has deeply rooted in American society. "From the first European venture to the New World up to the exodus to the West coast, games of chance have been a significant part in the American experience and have never ceased to inspire the American imagination" (Muhni, 2010, p.29).

The form of gambling has changed over time, from the conventional way up to the modern way by using machine. There are, nowadays, many online gambling provided by some sites, for example

$<$ www.americancasinoguide.org $>$;

$<$ www.americangaming.org $>$; or

$<$ www.us.casino city.com $>$. They also provide organization if people want to do charity while gambling. Moreover, the practice of this tradition is also supported by the government of the United States of America by conducting the US Green Card in the lottery. The advertisement states, "Immigrate easily to
America with the chance of winning in the USA Green Card Lottery. Now you also can live, work and study in United States of America and win in the Green Card Lottery" and also "Every year the US government makes available 50,000!!!! Green Cards through the Green Card Diversity Immigration Visa Program. The Green Card lottery is open to everyone, and YOU can apply and win US green card in the lottery" (Green Card Lottery, 2011).

Based on the gambling tradition occurring in the fact of America, many American writers depict this phenomenon into their works. They "often depict one or another aspect of the ambivalent attitude of the American society toward gambling" (Muhni, 2010, p.30). One of those authors is Shirley Jackson with her well-known "The Lottery". As born and grown up in United States, Jackson must have been very familiar with the game of gambling. However, her point of view in telling the story is quite opposite to the American people in general. This paper attempts to explore the lottery gambling as preserved tradition in the United States of America and its impacts toward other countries' lottery development, especially Indonesia. This paper tries to be objective, thus in this analysis, there will be both positive and negative response toward, as well as the benefit and loss of the existence of 
lottery gambling tradition in "The Lottery" as the portrayal of the culture in American society. In the following discussion, the quotation of the short story is taken from $<$ www.d.umn.edu>

\section{SHIRLEY JACKSON AND “THE}

\section{LOTTERY"}

Shirley Jackson began to write "The Lottery" after reading a book shown by her husband which tells about ancient rites of human sacrifice. She was "certainly aspired to be more that an entertainer; her concern with sorceries, ancient and modern, was authentic and even pragmatic"

(Bloom, 2001, p.10), It is quite interesting that the process of human sacrifice depicted in this story is performed through some sort of a "ritual" the villagers have to carry out every single year on June $27^{\text {th }}$. The ritual is done by drawing a lottery by each of the villagers including children. The lottery in this short story is a regular event that happens every year, where one unfortunate person becomes "the excluded one".

There is no specific purpose directly told in this story of the reason in holding lottery event. However the villagers believe that by holding this ritual, their village will continue to prosper.

Old Man Warner snorted. "Pack of crazy fools," he said. "Listening to the young folks, nothing's good enough for them. Next thing you know, they'll be wanting to go back to living in caves, nobody work any more, live hat way for a while. Used to be a saying about 'Lottery in June, corn be heavy soon.' First thing you know, we'd all be eating stewed chickweed and acorns. There's always been a lottery," he added petulantly. (lines 128-132)

Jackson's idea has been influenced by her way of living that she grew up in the West and ended up moving to Northeast. The human sacrifice as one of the elements in the story, somehow, reminds people of Salem witch trials. But, in the short story, Jackson mixed the human sacrifice with drawing lottery. The person who draws the slip of paper having a black spot in it is chosen to be stoned to death.

Bill Hutchinson went over to his wife and forced the slip of paper out of her hand. It had a black spot on it, the black spot Mr. Summers had made the night before with the heavy pencil in the coal company office. Bill Hutchinson held it 
up, and there was a stir in the crowd. (lines 205-207)

Tessie Hutchinson was in the center of a cleared space by now, and she held her hands out desperately as the villagers moved in on her. "It isn't fair," she said. A stone hit her on the side of the head. (lines 216-217)

Two momentous events pointed in the story, which are lottery gambling and human sacrifice, are two traditions practiced by American people in the past. Although human sacrifice has no longer exists nowadays, it still can be circumstantially experienced in the process of playing gamble.

"The Lottery" is different from the common American gambling in the aspect of purpose. A lottery is a form of gambling which involves the drawing of lots for a prize. But, in the short story, the person gets the lottery is thrown stones to death instead of gaining a prize. However, the form of this tradition is the same. This implies that gambling is either good or bad thing to do. In doing gambling, people tend to make themselves as the survivors for the purpose of life. In the story, no one looks brave to draw the lottery out of the black-box because they know if they win, they will die. In common gambling in
American society, people are in competition to win the prize which is usually in the form of money.

In this short story, "The Lottery", the villagers are described as friendly people and the neighborhood lives in a livable life. But when the time coming for drawing the lottery, their human characteristic emerges which is a will to live. They even sacrifice their own neighbors to save their own leaves. This characteristic can also be noticed in the practice of gambling found in American social life.

\section{THE BENEFIT AND THE LOSS OF LOTTERY GAMBLING}

There have been many reasons that lottery became famous in the era of colonies and vice versa. The establishment of lotteries had a purpose to raise revenue. It "helped establish some of the nation's earliest and most prestigious universities -- Harvard, Yale, Columbia, Dartmouth, Princeton, and William and Mary and also was used to build churches and libraries" (Dunstan, 1997, p.17). In line with the success of establishing lottery, a problem emerged. It "became an issue in the drive for independence of the colonies that they protested the crown's rules for holding lotteries. In 1769 , the crown tried to prevent 
lotteries from occurring without its permission" (Dunstan, 1997, p.17).

The villagers in "The Lottery" keeps on practicing their ritual for the reason that it is believed to be in good stead for their village, like the words said by one of the characters, Old Man Warner: "Lottery in June, corn be heavy soon" (line 130). The other point that shows the advantage of holding the lottery event is all the villagers are able to gather in the square and greet one another just like celebration. It looks like a cheerful moment in the outside, but each of the villagers actually feels nervous.

The morning of June 27th was clear and sunny, with the fresh warmth of a fullsummer day; the flowers were blossoming profusely and the grass was richly green. The people of the village began to gather in the square, between the post office and the bank, around ten o'clock... (lines 1-3)

The lottery was conducted--as were the square dances, the teen club, the Halloween program-- (line 22)

Soon the men began to gather. Surveying their own children, speaking of planting and rain, tractors and taxes.
They stood together, away from the pile of stones in the corner, and their jokes were quiet and they smiled rather than laughed. (lines 15-17)

The lottery tradition held in the village definitely gives a big fear for the villagers. They have to nervously prepare themselves every year just in case they are selected as the victim. They even want or try to suggest to quit doing the lottery.

"They do say," Mr. Adams said to Old Man Warner, who stood next to him, "that over in the north village they're talking of giving up the lottery." (lines 126-127)

"Some places have already quit lotteries."

Mrs. Adams said. (line 133)

It seems to suggest that the lottery practiced in that village is a brutal event that causes death to someone and brings fear on others. This practice is, of course, much more dangerous that can give a death blow for its performers. In American society, from past to present "Lotteries have traditionally been viewed as 'soft' forms of gambling which are assumed to have few negative effects" (Griffiths and 
Wood, p.2). However, there are still negative points as well as the positive ones that can be investigated in American society nowadays whether it may lead to more beneficial effects or vice versa.

The first thing concerning playing gamble nowadays is money. "Gambling is heavily regulated because of concerns about criminal involvement. Because of the large amount of cash involved, gambling is an attractive target for criminals" (Dunstan, 1997, p.2). People may spend all their money to purchase lottery tickets, pari-mutuel bets, playing casino table games or slot machines and they suddenly become either super poor or super rich. "Those who buy tickets want to get more than their money's worth. Some of them, if not all, are believers in their own good luck, and expect to get more than they pay for" (Proctor, 1887, p.63). "Some also criticize lotteries as inappropriate enterprises that redistribute income by taking money from the poor and making millionaires, suggesting that some of these new millionaires are unprepared for their wealth and do not use it responsibly" (Thompson, 2001, p.231). The demand of earning a mint of money may trigger someone to do crimes. The forms of the criminal actions may be various that people commit crimes by cheating or even robbing and killing. "Suicides, duels, and murders have frequently resulted from gambling here as elsewhere. Many of the duels in dark rooms originate in disputes at the gaming table. The combatants rush from play to an upper or adjoining room, and settle their difference with revolver-shots, often fatal to both" (Steinmetz, 1870, p.5).

In the social life, American people have two opposite views toward gambling. "Gambling is regarded by some as a vice, a sinful activity which corrupts society. Others view gambling simply as a harmless form of entertainment" (Dunstan, 1997, p.1). As there are negative effects caused by playing gamble in the present days, it is necessary to view the positive effects as well. In playing gambling, most people tend to do it in leisure time. They search for enjoyment by spending their money in casino table or slot machine. This behavior is actually the same with the enjoyment of shopping for some women or playing video games for some children. The enjoyment the need is for releasing their stress or tiredness by having some fun. "In 1995, gambling in the United States grossed over $\$ 40$ billion in revenues. Gambling is clearly a major form of entertainment" (Dunstan, 1997, p.2). It suggests that the form of having fun in the United States is playing gamble. Moreover, this event has been legally approved by the government in most of the states. This implies 
that American people are able to play gamble anywhere and anytime without being afraid to be arrested.

\section{AMERICAN SOCIETY'S VALUE TOWARD GAMBLING}

The American gambling tradition has occurred in American society since $17^{\text {th }}$ century in which an English lottery was held to help establish settlers in the first permanent English colony at Jamestown, Virginia. "For many Americans, games of chance or gambling, provide the means to realize their dreams and ambition for better living" (Muhni, 2010, p.1). It is the primary reason that society in the publication time of "The Lottery" gave hateful feedback. "In a generic sense, the word lottery can cover almost any form of gambling. The word has been applied to any game that offers prizes on the basis of an element of luck or chance in exchange for consideration, that is, something of value" (Thompson, 2001, p.229). The prize and the chance are two words that give hope for some American people to change their life into better one, though it is not always succeeded. "During the later 1940s many city councils across America sponsored weekly cash-prize lotteries that would draw people together in rural communities and were meant to spark commerce for the local merchants" (American Literature, 2011, p.26). The ending scene described where the "winner" of the lottery is stoned to death is the second reason. Readers interpreted the story as an attack on the values of small towns America. By the time it was published, America began to heal from the shock after World War II. The brutality shown in the story is far from the expression needed by American society to make recovery.

\section{IMPACT OF AMERICAN LOTTERIES ON THE DEVELOPMENT OF LOTTERIES AROUND THE WORLD, ESPECIALLY IN INDONESIA}

Gambling is a worldwide interest. This view is based on facts that many forms of gambling are flourished, they are slot machines, lottery, scratchcards, poker, blackjack, roulette, bingo, sports betting and racing, and online gambling. Gamblers have their own reasons for gambling. One reason is to relieve boredom and give a buzz. The other one is to enjoy the challenge or competition. Whatever the reasons, gambling can be really addictive (BigDeal, 2013). There are some examples that gambling occurs around the world as translated from Perpustakaan Online Menara Pengawal (2002): 
John, growing up in Scotland, has a dream to win a lottery. "I buy a lottery ticket every week," he says. "The price is not expensive, but this ticket gives me hope to get everything I want."

b. Kazushige, living in Japan, is addicted to horse racing. "Gambling at the racetrack together with my friends is extremely fun, and sometimes I won a large sum of money" he recalls.

c. "Bingo is my favorite game," says Linda, who lives in Australia. "This habit makes me spend about 30 dollars a week, but once I win, it feels good."

They are a few examples of hundreds millions of people around the world who are addicted to gambling. This phenomenon occurs as the society allows it to occur. It is also inseparable from the role of a certain government that provides gambling facilities and makes this activity flourishing and growing even larger. As mentioned previously that United States of America has Las Vegas where people around the world can play gambling freely. "The destination resort casino industry in Las Vegas is the largest and most dynamic of any casino industry in the world" (Eadington, n.d, p.3). This place has become interesting for visitors around the world to enjoy the entertainment facilities provided. "Las Vegas-which in 1997 attracted over 30 million visitors per year to its 105,000 hotel rooms and myriad casino and entertainment facilities-had become an ideal tourism destination resort, centered around casinos. Inspired by the phenomenal growth and economic success of Las Vegas, many other jurisdictions have authorized numerous forms of legal gambling —including casinos-for various reasons, including tourism development" (Eadington, n.d, p.1-2). In Europe, there is Switzerland which "has the highest density of casinos within Europe. There are 19 casinos within Switzerland, offering a total of 243 tables et 3,245 slot machines" (Centre du Jeu Excessif, 2011). South Africa has Sun City as its luxury casino and resort, and China has Macao which territory's economy is heavily dependent on gambling and tourism. In Southeast Asia, there is Singapore in which to boost its tourism industry, in 2005 the government legalized gambling and developed two casino resorts in Marina Bayfront and Sentosa which is called Integrated Resorts (Loong, 2005). Another casino resort which is the only legal landbased casino in Malaysia is called Genting Highlands which is also known as the 'Fun City above the Cloud'.

Following the widespread increasingly widespread and growing gambling resorts in 
other countries, Indonesia is without a doubt affected. It is also exacerbated by the development of casino resorts in two countries very close to Indonesia, which are Singapore and Malaysia. Not a few of Indonesian people are flocking to the resorts to gambling or just travelling. The result is that Indonesian government revenue is affected because of the great amount of money flowing out of the country as a result of the proliferation of gambling in those two countries. To deal with it, Indonesian government issued policies under the pretext of raising funds for social purposes. These are policies which have been issued by Indonesia government concerning gambling, rewritten and translated from Indra Fibiona (2013), are:

a. Indonesian government managed 'Dana Harapan'lottery which also known as 'Undian Harapan' in 1978 which was run by

'Yayasan Rehabilitasi Sosial'. The lottery draw result was used to coping social problems, but then it was closed after its inability to meet the required funds and being protested by the society.

b. Indonesian government made a new policy by releasing 'Sumbangan Sosial
Berhadiah' (SSB) which was suspected as disguised gambling. It used coupon which was printed for about 4 million pieces and then drawn once every two weeks. The funds which were successfully obtained until 1985 from these coupons were distributed for social and humanity purposes.

c. Indonesian government expanded to sport in 1986 by issuing 'Pekan Olah Raga dan Ketangkasan' or 'Porkas' originated from the word 'Forecast' which was a means to raise funds for sport. Many people denied that 'Porkas' was not a form of gambling, but many also found otherwise. Lottery 'Porkas' was actually almost similar to the lottery or toto in Spain in 1985 in which to guess the outcome of football matches over 14 professional clubs in the top division of that country. The chance to win 'Porkas' was

1:10 millions, which meant someone should to buy 10 million coupons and filled in 10 million chances to get the main prize.

By releasing these policies, Indonesian government has managed to suppress the flow of funds out of the country by gaining hundreds of billions rupiahs from those practices. Those policies are proofs that even 
though Indonesia is a religious country, both government and society are trying to preserve the practice of gambling.

\section{INDONESIAN PEOPLE VIEWS TOWARD LOTTERY GAMBLING IN THEIR COUNTRY}

It seems a common thing nowadays that gambling can be found anywhere and anytime in Indonesia. Although this activity is illegal and is incompatible with values and norms of Indonesian society, people still do it as a form of lifestyle. The government attempted to make positive results from issuing the mentioned policies. However, the negative impacts of these policies occurred around the country. As has been insinuated in the form of caricatures in the 'Berita Nasional Yogyakarta', farmers became lazy and unproductive. Every day they just filled in 'Porkas' code to try their luck winning lottery prizes (Fibiona, 2013, p.23). Middle class society and poor society were carried away by the lure to make them rich instantly. Those people did not calculate their daily needs but spent most of their money into lottery coupons. This resulted in the decreasing of merchants' income ahead of the coupon drawing. Not only that, education and health issues are also affected which might lead to worse situation for young generations. This lottery practice was not only influenced the society financially, but also socially. Crime was increasing and became a major issue, especially fraud. With many people protested this form of lottery practice, the government eventually erased it in 1993. However, another problem arouse for illegal gambling was growing, such as 'Toto Gelap' or known as 'Togel' and also Singapore Lottery. This illegal gambling emerged as a result of addiction and assumption that lotteries served as the solution of financial problems.

\section{CONCLUSION}

As gambling has been occurred in American society since $17^{\text {th }}$ century, this practice has become a tradition which can be found in American social life. As tradition, gambling practice has developed from time to time. People played gambling in the past conventionally. It is developed, then, that people build a machine to help them play gambling, as well as to make gambling more interesting. Nowadays, people even gamble creatively by using internet. They make online gambling so that all people in the world can participate, even though their home, without going into certain places which provide this 
game. "The Lottery" by Shirley Jackson portrays this tradition keeps being preserved by American people in line with both its negative and positive effects. This preservation leads United States of America financially from tourism sector which is influenced by the development of Las Vegas as casino resort.

Inspired by the success of United States of America, other countries around the world compete each other to develop similar casino resorts. With the fast growing and widespread of these kind of resorts, Indonesian government struggled to suppress funds people spent for gambling or just travelling to those resorts by making policies which was claimed not as a form of gambling, but the process was similar to lotteries by drawing coupons. These policies also have positive and negative impacts for Indonesian people. However, as this lottery demanded a lot of money to buy coupons, people began addicted. Most of their monthly or daily income was used to buy coupons causing inability to fulfill their proper daily needs. It resulted in high level of crime, especially fraud and illegal lottery gambling.

Lottery gambling is a game, which for some people it is considered as a means to enjoy their lives and for some other people it is belief to be the solution of their financial problems. The forms, the ways and the intentions of people around the world do lottery gambling are similar. After all, lottery gambling makes people addicted.

\section{REFERENCES}

American Literature. (2011). Shirley Jackson. Available at: <http://www.ame ricanliterature.com/author/shirleyjackso-n/bio-books-stories>. Accessed on: 5 July 2011.

BigDeal. (2013). Why Do People Gamble? London. Available at: <http://www. bigdeal.org.uk/gambling-explained-whydo-people-gamble--27>. Accessed on: 3 Oct 2013.

Bloom, Harold, ed. (2001). Shirley Jackson: Bloom's Major Short Story Writers (Comprehensive Research and Study Guide). Broomall: Chelsea House Publishers.

Centre du Jeu Excessif. (2011). Different Types of Gambling. Available at: $<$ http://www.jeu-excessif.ch/pages/en/B02.htm>. Accessed on: 2 Oct 2013.

Dunstan, Roger. 1997. Gambling in California.

Sacramento: California Research
Bureau. Available at: $<$ http://www.library.ca.gov /crb/97/03/crb97003.html\#toc>. Accessed on: 12 June 2012.

Eadington, William R. n.d. The Spread of Casinos and Their Role in Tourism Development. Forthcoming in Contemporary Issues in Tourism Development. Douglas G. Pearce and Richard W. Butler (Eds.). London and New York: Routledge. Available at: $<$ http://www 
midland.ca/ws_par/groups/public/@pub/ @ midland/documents/web_content/wsp ar_036984.pdf. $>$. Accessed on: 2 Oct 2013.

Fibiona, Indra. 2013. Dari Undian Dana Harapan, SSB Hingga SDSB, Kebijakan "Lotere legal" Sumbangan Berhadiah. Available at: $<$ http://indracuin.blogspot.com/2013/03/d ari-undian-dana-harapan-ssbhingga.html>. Accessed on: 1 Oct 2013.

\section{(2011) Green Card Lottery.}

Available at: $<\mathrm{http}: / /$ www.americagreen card.org/>. Accessed on: 5 July 2011.

Griffiths, Mark D and Richard T.A. Wood.

Lottery gambling and addiction: An overview of European research. Notting ham Trent University: Psycho-logy Division. Available at: $<$ https://www. european-lotteries.org/data/info_130/Wo od .pdf $>$. Accessed on: 12 June 2012.

Loong, Lee Hsien. (2005). Proposal to Develop Integrated Resorts. Statement By Prime Minister Lee Hsien Loong On Integrated Resort On Monday, 18 April 2005 At Parliament House (Press release). Min istry of Trade and Industry. Available at: $<$ http://web.archive.org/web/200711270 0719/http://app.mti.gov.sg/data/pages/60 6/doc/Ministerial\%20Statement\%20\%20 PM\%2018apr05.pdf $>$. Accessed on: 4 Oct 2013.
McDowell, Tremaine. (1948). American Studies. Minneapolis: The University of Minnesota.

Muhni, Djuhertati Imam. (2010). Bunga Rampai dari Amerika (American Bouquet). Yogyakarta: IMPULSE.

(2002) PERPUSTAKAAN ONLINE Menara Pengawal. Judi-Suatu Daya Tarik Global. Available at: <http://wol .jw.org/id/wol/pc/r25/lpin/1200272317/1 6/2>. Accessed on: 1 Oct 2013.

Proctor, Richard A. (1887). Hance and Luck: A Discussion of the Laws of Luck, Coincidences, Wagers, Lotteries, and the Fallacies of Gambling; with Notes on Poker and Martingales (Second Edition). London: Longmans, Green, and Co.

Steinmetz, Andrew Esq. (1870). The Gaming Table: Its Votaries and Victims in all Times and Countries, especially in England and in France Volume I (of II). [EBook \#466] Project Gutenberg EBook.

Jackson, S. (1948) The Lottery. Available at: $<$ http://www.d.umn.edu/ csigler/PDF $\% 2 \quad$ 0files/jackson_lottery.pdf $>$. Accessed on: 9 June 2012.

Thompson, William N. (2001). Gambling in America: An Encyclopedia of History, Issues, and Society. California: ABC-CLIO, Inc. 
